\title{
Grade 12 Learners' Perceptions of Opportunities to Learn Imperfect Market Structures: Frances Baard District
}

\author{
Wellington Itai Manzi, Moeketsi Mosia, \\ Boitumelo Moreeng and Thomas Masvosve \\ University of the Free State, Blomfontein, South Africa \\ https:// orcid.org/0000-0002-2212-152X \\ https://orcid.org/0000-0002-7189-0018 \\ https:// orcid.org/0000-0002-3644-3140 \\ https://orcid.org/0000-0002-2702-9677
}

\begin{abstract}
This empirical study sought to investigate the grade 12 economics learners' perceptions of opportunities to learn imperfect market structures in selected schools in the Francis Baard District of Northern Cape. A quantitative research approach was employed, where a questionnaire was administered to 253 Grade 12 economics learners from three schools in Galeshewe. The questionnaire was based on four Opportunities to Learn (OTL) variables; content exposure, content emphasis, quality of instruction, and instructional resources. Data were analysed through excel 365 and then through SPSS. Overall, the study showed that little or no opportunities to learn were being created for learners to master the concept of imperfect market structures. This study is significant because it helps to make known to both the learners and teachers, the factors influencing learners' learning outcomes related to imperfect market structures. Learners must also be encouraged to exhibit a positive attitude towards the subject, while the economics teachers should put in the required effort to improve the learning outcomes in schools.
\end{abstract}

Keywords: imperfect market structures; Opportunities to Learn (OTL); learning outcomes; academic achievement

\section{Introduction}

Globally, there has been a growing realisation of the importance of education to realise the growth and development objectives of countries (Moosavian, 2015). It is increasingly becoming clear that education is one of the greatest investments a nation can make if it is to grow and develop its economy. The education system should present learners with opportunities to acquire knowledge and skills required in a global, knowledge-based economy. For the requisite knowledge and 
skills to be attained, the education system should be concerned more with the way the content is taught, than with what is actually taught. (Marks, 2020).

Economics is one of the subjects that can be used as a foundation for achieving growth and development of countries. Morgan (2015) notes that a successful economics education should produce citizens who are well informed, responsible, and critically aware of economic issues, and are able to contribute effectively to the deliberations regarding issues of social provisioning. Economics is defined by Arsaythamby and Julinamary (2014, p. 240) "as a subject that integrates theoretical skills, calculations, graphs, tables, and equations to answer economic questions". As an economics concept, imperfect market structures is one example of curriculum content that exposes learners to the knowledge and skills postulated by scholars such as Arsaythamby and Julinamary (2014).

Imperfect market structures are market structures where there is some degree of unfair competition (Department of Basic Education 2014). This concept, as Hoag and Benedict (2010) would suggest, presents learners with situations that are complex, with no easy solutions; and therefore, stimulates learners' problem solving, critical thinking, and decision-making skills. Arsaythamby and Julinamary's (2014) assertion that, for learners to be able to calculate the above variables, they should be able to recall concepts, interpret figures and use mathematical skills to solve problems. Harsh and Schmitt-Harsh (2016) go further and argue that proficiency in graphing is considered a central element of scientific literacy, given the need for succinctly communicating complex information. In fact, Khoo and Fitzgerald (2017) believe that economics consists mainly of mathematics, graphs, and working with formula. More so, prior research reveals a clear link between mathematics training and success in economics courses (Hoag \& Benedict, 2010).

In trying to understand why most learners across the world struggle with content which involves mathematical concepts, Khoo and Fitzgerald (2017) opined that learners have a phobia for figures, and therefore, tend to generally struggle with mathematical and graphing skills embedded in imperfect market structures. In fact, Gultepe (2016) more specifically states that learners struggle with identifying relationships between variables, interpreting graphs, converting tables into graphs, and identifying trends in the data given. The skills of interpretation, comparison, and decision making through graphical and mathematical skills demand learners to be critical thinkers. Regrettably, as scholars like Ogbonnaya et al., (2020) posit, learners are able to tackle problems on market dynamics as they are, in most cases, not taught to think as economists. They are also not taught to learn independently, and they rarely pick up these complex skills on their own.

\subsection{Problem}

The study problem is the mediocre to poor academic achievement in high school economics. Whilst scholars argue and present evidence that learners seem to lack critical skills developed in economics, the current paper argues that there is a gap in literature which fails to account for what opportunities to learn are provided for the grade 12 learners to acquire these skills. The foregoing argument is foregrounded by scholars such as Cueto et al. (2014), who posit that it is to get a deeper insight, not only on the academic achievement outcomes of learners, but 
also on the processes of learning that take place in the classes. Thus, this paper seeks to investigate what opportunities to learn imperfect market structures are availed to grade 12 learners of economics.

\section{Literature Review and Conceptual Framework}

This review of literature sought to answer the question what is currently known about the constructs of OTL and imperfect market structures. The concept Opportunities to Learn (OTL) owes its origins to mathematics achievement research studies which were conducted by the International Association for the Evaluation of Educational Achievement (IAEEA). At the time, it was used to ensure comparability and validity of cross-national comparisons undertaken in the First International Mathematics Survey in the early 1960s (Gau, 1997; Boscardin, et al., 2005).

The OTL concept, as viewed by Scheerens (2016), operationalises what takes place in schools and classrooms that support learners' learning and progress. The scholar opines that OTL helps to reveal how the way learners are taught can have an effect on their academic achievement. The scholar argues that OTL helps establish the appropriateness of both the curriculum and pedagogy relative to the standards established for the learners' performance

A study of literature (Chabongora \& Jita, 2013; Cueto et al., 2014; Scheerens, 2016) reveals, there is a positive relationship between opportunities to learn and the learners' academic performance. This OTL concept suggests that content exposure, content emphasis, instructional strategies, and instructional resources, have a bearing on learners' academic achievement. As posited by Chabongora and Jita (2013), the nature of OTL can either enhance or hinder the learning experiences in an imperfect market structure classroom. It is because of this, that the researchers settled for the OTL concept since he wanted to investigate learners' perceptions of opportunities to learn graphical and mathematical skills

In trying to examine such opportunities,OTL researchers such as Banicky (2000), Chabongora and Jita (2013) distinguish three overlapping categories of concern; curriculum content, instructional strategies, and instructional resources.

As Chabongora and Jita (2013) suggest, the facet of curriculum content is concerned with the extent to which learners are exposed to topics that are essential to attaining standards. It is their contention that content exposure, content coverage, and content emphasis all play a significant role in determining the opportunities for learning presented to the learners. Content exposure is determined by the time taken by the teacher to cover specific content. Desimore (2016) confirm the importance of time spent on tasks as their research findings suggest a correlation between academic achievement and the time taken in covering the content. Content emphasis, in the view of Cueto et al. (2014), is concerned with establishing how a topic or content area is treated; whether it was treated as a major topic or minor topic, or whether the topic or content was not taught at all. Scholars like Aguirre-Munoz and Boscardin (2008) and Boscardin, et al. (2005) opine that higher levels of content coverage have been positively associated with learners' academic performance. According to Jita and Chabongora (2013) instructional strategies are concerned with whether students 
have been exposed to the kinds of teaching and instructional experiences that would prepare them for success. Asikhia (2010) writes that the poor academic achievement in economics is partly attributable to the ill-preparedness of teachers, and Van Wyk (2011) attributes this ill preparedness to the lack of pedagogical content knowledge. As a result of inadequate preparation, teachers may heavily rely on the teacher chalk strategies, where learners rarely take part in the learning process. The lack of pedagogical content knowledge, it can be argued, can manifest itself in teachers hurriedly going through important concepts as they are not confident to teach the concepts. Without adequately prepared and knowledgeable teachers, there is little chance that quality curriculum and instructional strategies will be implemented effectively.

Instructional resource variables are concerned with such issues as textbooks and teacher preparation; including levels of education, amount of experience, type of experience, participation in in-service professional development, and attitudes (Chabongora \& Jita, 2013). Teachers must make use of a variety of resources if meaningful learning is to take place. It is Chabongora's (2011) contention that schools' instructional resources continue to be an important OTL indicator because they can enable or constrain a schools' ability to provide a high-quality instructional programme. Affirming the importance of instructional resources, Reche et al. (2012) observed that the adequacy and use of teaching and learning material influence the effectiveness of a lesson. As part of the early work in this body of knowledge, Reche, et al. (2012) held the belief that, if teachers fail to use teaching and learning material adequately, the effectiveness of the teacher's lesson is compromised, and consequently, learners are denied the opportunity to learn imperfect market structures. The impact of the availability of opportunities to learn is summarised by Confucius who said "I hear, and I forget. I see, and I believe. I do, and I understand". The challenge with opportunities to learn with regards to the teaching and learning of imperfect market structures is not a uniquely South African problem. Zhang (2017), for instance, reveals that there are many countries where teachers face challenges related to meaningfully engaging learners. A further review of literature by Minarni et al. (2016) shows that there is poor learner achievement in topics that include mathematical concepts in Public Junior High School in Indonesia. These scholars attribute this to the teaching approaches employed by the teachers, the type of learning material, and the rare engagement of learners in solving mathematical problems in economics, as is the case with imperfect market structures. Moreover, Minarni et al.'s (2016) assertion is confirmed by Zhang (2017) who also bemoans the lack of content knowledge, lack of adequate resources, and inefficient use of available instructional resources as the reasons for poor academic achievement in economics. Minarni et al. (2016) suggest that the teacher should teach the learners in such a way that the learner has an opportunity to solve mathematical problems, as well as to understand mathematical representation in the form of graphs and tables.

Given the above overview, it can be concluded that the most influential factors in learners' academic achievement correlate with the opportunities to learn in the classroom.

http://ijlter.org/index.php/ijlter 
The quality of interaction of the two main actors - the learner and teacher - has a bearing on learners' academic achievement. In fact, Beniwal (2016) argues that there is need to differentiate instruction to meet individual learners' needs, and to provide active learning opportunities for learners to master economics. He further argues that these strategies should motivate, engage, and prompt learners to learn and achieve. In her book titled Teaching at its Best, Nilson (2010) posits that learners should be taught in multiple ways. She further argues that learners should be given the opportunity to read, talk, hear, see, act, draw, and feel their learning material. This, she argued, would bring fairness and equality in the learning process, as different learners prefer to learn in different ways.

\section{Research Methodology}

This study sought to investigate what opportunities to learn imperfect market structures were available to the grade 12 economics learners. To achieve this, the study employed a quantitative descriptive survey. Quantitative research is viewed by Leedy and Ormrod (2019) as research that is concerned with providing answers to questions about relationships among variables being measured, with the objective of explaining phenomena. Neuman (2003) argues that a survey technique is relevant for descriptive or explanatory research. The researchers found this approach relevant to describe the learners' experiences of opportunities to learn imperfect market structures through the presentation of statistical results.

\subsection{Sampling and Research participants}

Three Galeshewe schools with comparable characteristics, in the rural district of Francis Baard in the Northern Cape served as the context of this study after permission was sought from the Francis Baard District Department of Education and the principals of the respective schools. The study participants were 253, 190 females and 63 males, between the age of 16 and 19 years of age and voluntarily agreed to participate in this research study with parental permission being sought for those participants who were below the age of 18 years

A clustered sample of learners studying Economics(n=253) in grade 12 in the three schools was used in this study. The target population was all the grade 12 Economics learners in the Frances Baard district. Because of the size of the district, it was divided into geographical areas/suburbs that formed different cluster cohorts. The three schools selected in this study belonged to the Galeshewe cluster and were randomly selected. The three schools chosen were also found to be homogeneous, since all participants came from Galeshewe(cluster) with similar socioeconomic backgrounds(Alvi, 2016). The minimums ample size was determined using the Yamane equation(Yamane,1967:886) as shown in Equation 1.

Equation 1: Yamane method of determining sample size

$$
\mathrm{n}=\mathrm{N} /(1+\mathrm{N}(\mathrm{e}) 2)
$$

Where:

n= the sample size $\quad \mathrm{N}=$ the population under study $\quad \mathrm{e}=$ the margin error 


\subsection{Instrumentation}

The researcher used a questionnaire to source data. A questionnaire is described by Khuc et al. (2021) as an instrument used to collect information through questions posed to the participants in writing. The selection of this instrument was based on Khuc et al.'s (2021) assertion that the prime objective of a questionnaire is to enable a researcher to gather informed facts and opinions about a phenomenon. In pursuit of ensuring validity of the questionnaire, the draft questionnaire was presented to experts in the Faculty of Education at Sol Plaatje University, and suggestions and corrections were made before the questionnaire was piloted to 30 learners from a local school. The main study participants were not used as samples in this pilot study. To ensure reliability of the instrument, the researcher made use of the test-re-test method and consistency of the instrument was measured through the Cronbach alpha which yielded $\mathrm{r}=0.86$. After two days the researcher personally went to collect the questionnaires and managed to get 240 questionnaires back, which was a return rate of $95 \%$. Four constructs of OTL, namely; content emphasis, content exposure, quality of instructional strategy, and instructional resources formed the basis of the questionnaire. Data presentation was descriptive and a five-point interval Likert scale was used to measure the responses. Leedy and Ormorod (2019) posit that a five-point scale is easy to comprehend and enables participants to express their views in a better way. In order to get a deeper understanding of the survey, the percentages of participants choosing strongly agree, agree, unsure, disagree and strongly disagree were calculated using excel.

\section{Ethical clearance}

The researcher obtained ethical clearance from the University of the Free State (South Africa) to conduct this research. Permission was also sought from the Francis Baard District Department of Education, principals of the respective schools, and from parents and learners. All ethical protocols were observed.

\section{Data Analysis}

The statistical analysis of the data obtained from the five-point Likert scale questionnaire was conducted using Microsoft Office Excel 365 and statistical software SPSS. The data from all the questions was analysed through the SPSS software. Each learner's average per construct was calculated for the four constructs on which the questions were based. Thereafter, the averages per learner for the four constructs were calculated.

\section{Findings}

This section presents findings in response to the question "What are the grade 12 learners' perceptions of opportunities to learn imperfect market structures?" The responses came from 240 learners of which 186 were females and 54 were males in the respective schools.

\subsection{Content emphasis}

Using the conceptual framework of OTL, content emphasis relates to how a topic or content area was treated. It seeks to ascertain whether a topic was treated as a minor or major topic. In this study, the researcher wanted to find out whether teachers placed emphasis on calculation of costs and revenues and drawing and 
interpretation of graphs, as these are critical skills and knowledge in the study of imperfect market structures.

The table below shows the learners' responses to the three items based on content emphasis.

Table 1: Results from learners' survey (227 responses)

\begin{tabular}{|c|c|c|c|}
\hline & \multicolumn{3}{|c|}{ Report } \\
\hline & $\begin{array}{c}\text { Emphasis on } \\
\text { Calculation of } \\
\text { Cost and } \\
\text { Revenues }\end{array}$ & $\begin{array}{c}\text { Detailed teaching of } \\
\text { drawing graphs }\end{array}$ & $\begin{array}{c}\text { Emphasis on } \\
\text { interpreting } \\
\text { graphs }\end{array}$ \\
\hline $\mathrm{N}$ & 227 & 227 & 227 \\
\hline Mean & 2.9295 & 3.1013 & 2.8370 \\
\hline Std. Deviation & 1.07438 & 1.13798 & 1.04112 \\
\hline
\end{tabular}

The results presented in Table 1 reveal a mean statistic of 2.93 on the emphasis on calculation of cost and revenues. On detailed teaching of drawing graphs, a mean of 3.10 was obtained and a 2.84 mean was recorded on the emphasis of graph interpretation. This suggests that the majority of the responses were between strongly disagreeing or disagreeing options. A standard deviation on the three items on the Table1 was averaging 1.08. This shows that the responses were tightly bunched close to the mean. Learners' responses on the three items were combined and an average for content emphasis was calculated. An average of the three on this construct was $86 \%$. This finding suggests that learners generally feel that not enough emphasis is placed on the concept

\subsection{Content exposure}

The construct of content exposure consisted of four items as shown in table 2.

Table 2: Results of learners' survey (233 responses)

\section{Table 2: $\quad$ Report}

Time spent on Time spent on Frequency of Time spent on calculations Cost how to draw assessment on graph

and Revenue graphs graphs $\quad$ interpretation

\begin{tabular}{l|l|l|l|l|}
\hline $\mathrm{N}$ & 233 & 233 & 233 & 233 \\
\hline Mean & 2.9914 & 3.1974 & 3.2060 & 3.3047 \\
\hline Std. Deviation & 1.14467 & 1.18707 & 1.03830 & 1.13594 \\
\hline
\end{tabular}

We can see from Table 2 above that the mean of all the four items under this construct of content exposure ranged between 2.99 and 3.30. These results suggest that most learners' responses were crowded on disagree option. (Option 3). The responses reveal that there is not enough time spent on calculations of costs and revenues, drawing of graphs, and interpretation of graphs. The results also show that there is less frequency of assessment of graphs. The averages of the four items of content exposure construct show that most learners did not agree that enough time was being spent on calculations of costs and revenues, graph construction, and interpretation. This is suggested by a huge percentage $(88 \%)$ of learners who 
disagreed and strongly disagreed on the four items of content exposure.

\subsection{Instructional strategies}

The table shows learners' responses on the four items of instructional strategies

Table 3: Result of learners' survey (228 responses)

Table 3: $\quad$ Report

Teachers are always $\quad$ Teacher uses

Teaching methods in command of Learners actively appropriate pace in are varied content participate in class teaching

\begin{tabular}{l|l|l|l}
\hline 228 & 228 & 228 & 228 \\
\hline 2.9868 & 3.2193 & 3.2368 & 3.1711 \\
\hline 1.13991 & 1.15540 & 1.02224 & 1.15787 \\
\hline
\end{tabular}

On whether teachers varied teaching methods, a mean of 2.99 was obtained, which points to most respondents disagreeing. The results also show a mean of 3.21 on whether teachers were always in command of their content. As in the former, the learners' responses were clustered around option 2 and option 3 (disagree and strongly disagree). On learners' active participation in class, a similar trend was observed where learners either did not agree or strongly disagreed with this assertion as shown by a mean of 3.23. As to whether teachers paced their lessons appropriately, a mean of 3.17 was recorded. This means that the majority of the respondents $(66 \%)$ either disagreed or strongly disagreed thatteachers paced their lessons appropriately. The result shows that learners do not actively participate in an imperfect market structure classroom.

The table below shows learners' responses on the amount of time teachers spend lecturing.

Table 4(a): Result of learners' survey on time spent lecturing (236 responses)

The average time teachers lecture

\begin{tabular}{lll|l|l|l} 
& & & & Cumulative \\
& & Frequency & Percent & Valid Percent & Percent \\
\hline Valid & $75 \%$ and above (1) & 80 & 33.9 & 33.9 & 33.9 \\
\cline { 2 - 6 } $75 \%(2)$ & 60 & 25.4 & 25.4 & 59.3 \\
\hline $50 \%(3)$ & 48 & 20.3 & 20.3 & 79.7 \\
\hline $25 \%(4)$ & 28 & 11.9 & 11.9 & 91.5 \\
\hline $10 \%(5)$ & 20 & 8.5 & 8.5 & 100.0 \\
\hline Total & 236 & 100.0 & 100.0 & \\
\hline
\end{tabular}

The findings reveal that teachers talk more in an imperfect market structure classroom as shown by the responses. On average, teachers talk $75 \%$ or more of the allocated teaching and learning time. 
Table 4 (b): $\quad$ Report

The average time teachers lecture

\begin{tabular}{l|l|l}
$\mathrm{N}$ & Mean & Std. Deviation \\
\hline 236 & 2.3559 & 1.28841 \\
\hline
\end{tabular}

The mean scores of learner responses on instructional strategies suggest that teachers employ less variation on strategies in class. In addition, the findings also show that learners are not actively involved in the teaching and learning of graphs and calculations in an imperfect market structures classroom. This assertion is based on most of the learners' responses on the instructional strategies construct being spread around strongly disagree and disagree (98\%).

\subsection{Instructional resources}

Table 5: Result of learners' responses on the frequent use of resources (240 responses)

\begin{tabular}{|l|l|}
\hline Percentages & $\mathbf{( \% )}$ \\
\hline & \\
1.1 Chalkboard & $\mathbf{8 0}$ \\
1.2 Textbooks and posters & $\mathbf{8 5}$ \\
1.3 Computers & $\mathbf{2 5}$ \\
1.4 Worksheets & $\mathbf{3 9}$ \\
1.5 Overhead projector and TV & $\mathbf{2 9}$ \\
\hline
\end{tabular}

The questionnaire on the use of instructional resources sought to establish how often teachers used resources such as worksheets, textbooks, chalkboards, projectors, televisions, computers, and specialised equipment such as calculators. The chalkboard and textbook were the most popular resources employed by teachers as shown by the high percentage of learner responses on the categories of the Likert scale. Computers and projectors were rarely used in imperfect market structure classrooms as evidenced by only $25 \%$ of the participants responding in the affirmative on their use.

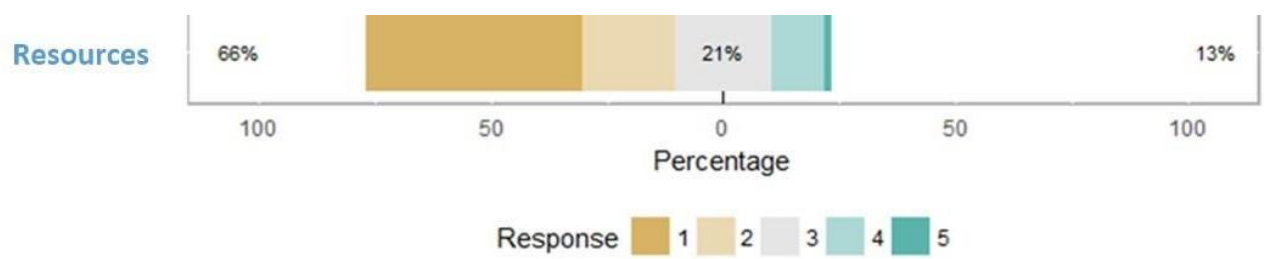

Figure 1: Average learners' responses on the five items of instructional resources construct

A huge percentage of the learners' responses $(66 \%)$ strongly disagreed and disagreed that there was a variation of instructional resources in the teaching and 
comfortable with. This could negatively affect learners' graphing skills as scholars such as Glazer (2011: p. 193) argue that learners' familiarity with content influences how they interpret and use data.

Whilst Beniwal (2015) argues for differentiation in instructional strategies, the findings of this study show that classes are characterised by teacher talk most of the time. There is invariably no adoption of the learner-centred approach as a variation method to adequately cover the concept, so that learners are empowered. This beclouds the concept, and learners are left in the dark. Despite Morgan's (2015) assertion that economics and imperfect market structures should help develop learners' problem-solving skills, the practices by teachers in the classrooms do not seem to be tailored to develop such skills. This observation is based on the premise that learners are rarely given opportunities to illuminate their own understanding, make sense of abstract concepts, and articulate their emerging ideas.

The study findings revealed that the most used resources in an imperfect market structure class were the chalkboard and textbooks. Although these can be effective resources in teaching calculations, over reliance on them might deny learners opportunities to learn calculations and graphs. This assertion is supported by Chabongora (2011) who argues that schools' instructional resources continue to be an important OTL indicator, because they can enable or constrain a school's ability to provide a high-quality instructional programme.

\section{Discussion and Implications}

\subsection{Content Emphasis}

The findings on content emphasis suggest that there was less emphasis on calculation of costs and revenues, and lack of detailed teaching and interpretation of graphs. The reason for the difficulty in understanding these concepts was probably because of little emphasis being placed on the calculations and graphs during teaching and learning of imperfect market structures. The minimal exposure to calculations was way inadequate compared to the desired outcomes. Cueto et al (2014) argue that main topics like imperfect market structures should be emphasised as they are major topics. However, this was the case with schools which were used in this study.

\subsection{Content exposure}

Although learners are exposed to calculations of costs and revenues, the extent of the exposure is minimal as less time is dedicated to developing these skills and knowledge. This finding conflicts with what literature recommends in terms of content emphasis. For instance, Arsaythamby and Juliminary (2014) posit that learners need to be exposed to calculations and manipulation of numbers in their pursuit for solutions to problems encountered in the economy. This was not the case in the selected schools. The study also revealed that learners were exposed to graphs as total pictures but were not taught the process of graph construction systematically. This way of teaching graphs made it difficult for learners to interpret these graphs when called to do so. For teachers, it could be the pressure to cover the syllabus playing itself out in the tension between the allocated time and the need to enhance meaningful learning. There was also the possibility, as 
argued by Van Wyk (2011), that teachers themselves had limited exposure to deeper mathematical and graphing knowledge, and they did not want to be exposed by spending more time on concepts that they themselves were not comfortable with.

\subsection{Instructional strategies}

Whilst Beniwal (2015) argues for differentiation in instructional strategies, the findings of this study showed that classes are characterised by teacher talk most of the time. There is invariably no adoption of the learner centred approach as an alternative approach to adequately cover the concept so that learners are empowered. This beclouds the concept and leaves learners in the dark. Another concern was that the practices by teachers in the classroom were not tailor-made to develop the intended skills of the economics curriculum, which include problem solving skills suggested by Morgan (2015). It is saddening that learners are rarely given opportunities to reveal their own understanding, make sense of abstract concepts, and articulate their emerging ideas.

\subsection{Instructional Resources}

The study findings revealed that there is overreliance on the two traditional resources (chalkboard and textbooks) at the expense of alternative resources that would have engendered hands-on engagement with concepts Whilst these can be effective resources in the teaching of calculations, over reliance on them might deny learners opportunities to learn and practice calculations and drawing of graphs. This assertion is supported by Chabongora (2011) who argues that schools' instructional resources continue to be an important OTL indicator, because they can enable or constrain a school's ability to provide a high quality instructional programme.

\section{Conclusion and Recommendations}

The analysis of the study findings showed that participants were not presented with sufficient opportunities to learn mathematical and graphing skills. In order to achieve the knowledge and skills envisaged in the economics curriculum, it is imperative that teachers listen to the emerging and incomplete ideas from the learners and guide them. This can only be achieved if active learner participation is prioritised, as encouraged by Bhattacharyya and Goswami (2020). There is need for teachers to place more emphasis on calculations as well as graph construction and interpretation. The Department of Basic Education (DBE) must continuously conduct teacher development (refresher) workshops where teachers are workshopped on the content itself (imperfect markets) as well as different pedagogies of delivering meaningful lessons for abstract concepts such as imperfect market structures. The researchers also noticed that there were pockets of good practice among schools which participated in the study. The study therefore, recommend that schools must create platforms where teachers can share their good practices. Furthermore, the article recommends that a more comprehensive study be undertaken, which considers the teachers' pedagogical content knowledge, especially in mathematical and graphing competence. Lastly, the researcher suggests that a further study be conducted, where a broader population sample is used to allow the generalisation of the findings across a broad spectrum. 


\section{References}

Aguirre-Munoz, Z., \& Boscardin, C. K. (2008). Opportunity to Learn and English Learner Achievement: Is Increased Content Exposure Beneficial? Journal of Latinos and Education, 7 (3), 186-205. https:// doi.org/10.1080/15348430802100089

Alvi, M. (2016). A manual for selecting sampling techniques in research. In Munic Personal RePEc Archive. https://mpra.ub.uni.muenchen.de/70218/1

Arsaythamby, V., Hariharan, N., \& Abdullah, W. S. W (2015). Types of Student Errors in Mathematical Symbols, Graphs and Problem-Solving. Asian Social Science, 11(15) https:// doi.org/10.5539/ass.v11n15p324

Arsaythamby, V. \& Julinamary, P. (2014). Students' Perceptions on Difficulties of Symbols, Graphs and Problem Solving in Economic. Social and Behavioural Sciences, 177, 240245. http://creativecommons.org/licences/by-nc-nd/4.0/

Asikhia, Q. A. (2010). Students and Teachers' Perception of the Causes of Poor Academic Performance in Ogun State Secondary Schools [Nigeria]: Implications for Counselling for National Development. European Journal of Social Sciences, 13(2), 229-242.

Banicky, L. A. (2000, October). Opportunity to Learn Education. Education Policy Brief, Vol. 7.

Beniwal, R. D. (2016). Best Practices in Teacher Education for Quality Enhancement. International Journal of Research in Economics and Social Sciences, 6(9), 258-263 http:/ / euroasiapub.org

Bhattacharyya, J., \& Goswami, B. (2020). Interactive Interventions to Enhance Attention of 1st year MBBS Students during Physiology Lecture sessions. International Journal of scientific research, 1-3. October. https://doi.org/10.36106/IJSR/0911141

Boscardin, C. K. Z., Aguirre-Muñoz, Z., Stoker, G., Kim, J., Kim, M., \& Lee, J. (2005). Relationship Between Opportunity to Learn and Student Performance on English and Algebra Assessments. Educational Assessment, 10(4), 307-332.

Chabongora, B. N. (2011). Investigating Opportunities to Learn Grade 10 Algebra: Case studies of three Catholic secondary schools [Thesis, University of South Africa].

Chabongora, B. N., \& Jita, L. C. (2013). Opportunities to learn (OTL) Grade 10 algebra in three South African Catholic secondary schools. Journal of Educational Studies, 12 (1),172-188. https://hdl.handle.net/10520/EJC157141

Cueto, S., Guerrero, G., Leon, J., Zapata, M., \& Freire, S. (2014). The relationship between socioeconomic status at age one, opportunities to learn and achievement in mathematics in fourth grade in Peru. Oxford Review of Education, 40(10), 50-72. https:// doi.org/10.1080/03054985.2013.873525

Desimore, L., Etikan, I., Musa, S. A., \& Alkassim, R. S. (2016). Comparison of Convenience Sampling and Purposive Sampling. American Journal of Theoretical and Applied Statistics, 5(1), 1-4. https:// doi.org/10.11648/j.ajtas.20160501.11

Gau, S. (1997). The Distribution and the Effects of Opportunity to Learn Mathematics Achievement [Paper presentation]. The Annual Meeting of the American Educational Research Association, Chicago, Illinois, USA.

Glazer, N. (2011). Challenges with graph interpretation: a review of literature. Studies in Science Education, 47 (2), 183-210. https://doi.org/10.1080/03057267.2011.605307

Gultepe, N. (2016). Reflections on High School Students' Graphing Skills and Their Conceptual Understanding of Drawing Chemistry Graphs. Educational Sciences: Theory \& Practice, 17(1), 53. https:// doi.org/10.12738/estp.2016.1.2837

Harsh, J., A., \& Smit-Harsh, M. (2016). Instructional Strategies to Develop Graphing Skills in the College Science Classroom. The American Biology Teacher, 78(1), 49-56. https:// doi.org/10:1525/abt.2016.78.1.49 
Hoag, J., \& Benedict, M. E. (2010). What influence Does Mathematics Preparation Have on Performance in First Economics Classes? Journal of Economics and Economic Education Research, 11(1), 19-24. https://doi.org/10.2139/ssrn.964539

Khoo, Y. Y., \& Fitzgerald, R. (2017). Peer Learning with Concept Cartoons Enhance Critical Thinking (CRiTT) and Performance In Secondary School Economics. Journal of Economics and Economic Education 18(1), 1-13. https://www.researchgate.net/publication/320728752

Khuc, Q. V., Pham, P., \& Tran, T. D. (2021). Questionnaire design. https://doi.org/10.31219/osf.io/q3um6

Leedy, P. D., \& Ormrod, J. E. (2019). Practical research. Planning and design Journal of Applied Learning \& Teaching, 1(2). https:// doi.org/10.37074/jalt.2018.1.2.15

Marks, N. (2020). Student Engagement in Improving Access to Taught Course Content at LSE Library: practicalities and Pitfalls. New Review of Academic Librarianship, 26(24), 403-418. https:// doi.org/10.1080/13614533.2020.1803937

Minarni, A., Napitupulu, E. E., \& Husein, R. (2016). Mathematical understanding and representation ability of public junior high school in north Sumatra. Journal on Mathematics Education, 7(1),45-58. https://files.eric.ed.gov

Moosavian, S. A. Z. N. (2015). A comprehensive visual "wheel of duality" in consumer theory: An instructional tool usable in advanced microeconomics to turn "pain" into "joy". A paper presented at the 8th annual International Atlantic Economic Society (IAES) conference, Boston, Massachusetts, USA.

Neuman, W. L. (2003). Social research methods: Qualitative and quantitative approaches. $5^{\text {th }}$ edition. Boston: Allyn and Bacon.

Nilson, L. B. (2010). Teaching at its best: A research-based resource for college. $3^{\text {rd }}$ edition. San Francisco: Jossey-Bass.

Ogbonnaya, C. I., Mafa-Theledi, N. O., \& Ngulube, B. (2020) Economics Teachers' Topic Pedagogical Content Knowledge Model for teaching Market Dynamics, International Journal of Learning, Teaching and Educational Research, 19(7), 320-341. https://doi.org/10.26803/ijlter.19.7.18

Reche, R. N., Bundi, T. K., Riungu, J. N., \& Mbungua, Z. K. (2014). Factors Contributing to Poor Performance in Kenya Certificate of Primary Education in Public Day Primary Schools in Namibia Division. International Journal of Humanities and Social sciences, 2(5), 127-133. https:// doi.org/0.5901/mjss.2014.v5n5p273

Scheerens, J. (2016). Educational Effectiveness and Ineffectiveness: A critical review the knowledge base. Dordrecht, Heidelberg, London, New York: Springer. https://doi.org/10.1007/978-94-017-7459-8

Yamane, T. (1967) Statistics, an introductory analysis, $2^{\text {nd }}$ edition. New York : Harper \& Row.

Van Wyk, M. (2011). The Use of Cartoons as a Teaching Tool to Enhance Student Learning in Economics. Journal of Social Sciences, 26(2), 117-130. https:// doi.org/10.1080/09718923.2011.11892888

Zhang, H. (2017). Accommodating Different Learning Styles in the Teaching of Economics: with Emphasis on Fleming and Mill's Sensory-based Learning Style Typology. Applied Economics and Finance, 4(1), 72-83. 


\section{Appendix 1}

\section{QUESTIONNAIRE FOR LEARNERS}

\section{Dear Learner}

This survey is being carried out as part of my efforts to complete my Med study titled 'Investigating opportunities to learn imperfect market structures in a selected grade 12 class'. Your participation is voluntary and there will be no mention of your name in the final article and any information given is treated confidentially. Please do not write your name anywhere on this questionnaire. Your cooperation and participation is greatly valued.

PLEASE JUST INDICATE BY TICKING IN THE BOX OF YOUR CHOICE.

\section{CONTENT EMPHASIS}

\begin{tabular}{|l|l|l|l|l|l|}
\cline { 2 - 6 } \multicolumn{1}{c|}{} & $\begin{array}{l}\text { Strongly } \\
\text { agree }\end{array}$ & Agree & Unsure & Disagree & $\begin{array}{l}\text { Strongly } \\
\text { disagree }\end{array}$ \\
\hline $\begin{array}{l}\text { 1.1 Does your teacher place emphasis on } \\
\text { calculations of costs and revenues? }\end{array}$ & & & & & \\
\hline
\end{tabular}

\begin{tabular}{|l|l|l|l|l|l|}
\cline { 2 - 5 } \multicolumn{1}{c|}{} & $\begin{array}{l}\text { Strongly } \\
\text { agree }\end{array}$ & Agree & Unsure & Disagree & $\begin{array}{l}\text { Strongly } \\
\text { disagree }\end{array}$ \\
\hline $\begin{array}{l}1.2 \text { Does your teacher go in detail in } \\
\text { teaching you how to draw graphs from } \\
\text { given tables showing costs and } \\
\text { revenues? }\end{array}$ & & & & & \\
\hline
\end{tabular}

\begin{tabular}{|c|c|c|c|c|c|}
\hline & $\begin{array}{l}\text { Strongly } \\
\text { agree }\end{array}$ & Agree & Unsure & Disagree & $\begin{array}{l}\text { Strongly } \\
\text { disagree }\end{array}$ \\
\hline $\begin{array}{l}\text { 1.3 Does your teacher emphasis on } \\
\text { interpreting data and } \\
\text { interpreting graphs? }\end{array}$ & & & & & \\
\hline
\end{tabular}


CONTENT EXPOSURE

\begin{tabular}{|l|l|l|l|l|l|}
\cline { 2 - 5 } \multicolumn{1}{l|}{} & $\begin{array}{l}\text { Strongly } \\
\text { agree }\end{array}$ & Agree & Unsure & Disagree & $\begin{array}{l}\text { Strongly } \\
\text { disagree }\end{array}$ \\
\hline $\begin{array}{l}2.1 \text { Allocated time for teaching and } \\
\text { learning is spent on the actual } \\
\text { teaching and learning of } \\
\text { calculations and graph in } \\
\text { imperfect market structures. }\end{array}$ & & & & & \\
\hline
\end{tabular}

\begin{tabular}{|l|l|l|l|l|l|}
\cline { 2 - 5 } \multicolumn{1}{l|}{} & $\begin{array}{l}\text { All the } \\
\text { times }\end{array}$ & $\begin{array}{l}\text { Most } \\
\text { of the } \\
\text { times }\end{array}$ & $\begin{array}{l}\text { Half } \\
\text { the } \\
\text { times }\end{array}$ & $\begin{array}{l}\text { Very } \\
\text { few } \\
\text { times }\end{array}$ & Never \\
\hline $\begin{array}{l}2.2 \text { How often are you taught } \\
\text { about calculations and graphs? }\end{array}$ & & & & & \\
\hline
\end{tabular}

\begin{tabular}{|l|c|c|c|c|c|}
\cline { 2 - 5 } \multicolumn{1}{c|}{} & $\begin{array}{c}\text { All the } \\
\text { times }\end{array}$ & $\begin{array}{c}\text { Most } \\
\text { of the } \\
\text { times }\end{array}$ & $\begin{array}{c}\text { Half } \\
\text { the } \\
\text { times }\end{array}$ & $\begin{array}{c}\text { Very } \\
\text { Few } \\
\text { times }\end{array}$ & Never \\
\hline $\begin{array}{l}2.3 \text { Do you receive some } \\
\text { Remedial/enrichment } \\
\text { opportunities such as monitored } \\
\text { homework, on graphs, tables and } \\
\text { calculations? }\end{array}$ & & & & & \\
\hline
\end{tabular}

\begin{tabular}{|l|l|l|l|l|l|}
\cline { 2 - 5 } \multicolumn{1}{c|}{} & $\begin{array}{c}\text { Strongly } \\
\text { agree }\end{array}$ & Agree & Unsure & Disagree & $\begin{array}{l}\text { Strongly } \\
\text { disagree }\end{array}$ \\
\hline $\begin{array}{l}2.4 \text { Does your teacher teach you } \\
\text { how to interpret graphs }\end{array}$ & & & & & \\
\hline
\end{tabular}




\section{QUALITY OF INSTRUCTION}

\begin{tabular}{|ll|l|l|l|l|}
\cline { 5 - 6 } \multicolumn{1}{l|}{} & $\begin{array}{l}\text { Strongly } \\
\text { agree }\end{array}$ & Agree & Unsure & Disagree & $\begin{array}{l}\text { Strongly } \\
\text { disagree }\end{array}$ \\
\hline $3.1 \quad$ Teaching methods are varied & & & & & \\
\hline $3.2 \quad \begin{array}{l}\text { Teachers are always in } \\
\text { command of the subject }\end{array}$ & & & & & \\
\hline $3.3 \quad \begin{array}{l}\text { Do you as learners actively } \\
\text { participate during classes? }\end{array}$ & & & & & \\
\hline $3.4 \quad \begin{array}{l}\text { Teachers use appropriate } \\
\text { place to cover the content. }\end{array}$ & & & & & \\
\hline
\end{tabular}

\begin{tabular}{|l|l|l|l|l|l|}
\cline { 2 - 6 } \multicolumn{1}{l|}{} & $10 \%$ & $25 \%$ & $50 \%$ & $75 \%$ & $75 \%+$ \\
\hline $\begin{array}{l}3.5 \text { On average, the teachers talk for } \\
\text { about what percentage of the time? }\end{array}$ & & & & & \\
\hline
\end{tabular}

